\title{
PERFORMANCE OF MUSTARD VARIETIES IN HAOR AREA OF BANGLADESH
}

\author{
Z Ahmed $^{1}$ and M A Kashem ${ }^{2}$ \\ ${ }^{1}$ Farm Productivity Improvement Project, Sylhet Agricultural University \\ ${ }^{2}$ Department of Soil Science, Sylhet Agricultural University, Sylhet-3100 \\ Corresponding author, E-mail: duafroza@gmail.com
}

Key words: Mustard, variety and haor areas

\begin{abstract}
A varietal trial of mustard was conducted at Noagaon village of Dekhar haor areas of south Sunamganj upazila of Sunamganj district, during November 2015 to March 2016, to find out the suitable mustard variety/varieties. A total of five varieties viz. BADC 1, SAU Sarisha-3, BARI Sarisha-11, BARI Sarisha-14 and BARI Sarisha-15 were tested in the farmer's field. The experiment was carried out in a randomized complete block design with three replications. Significant differences were found among the mustard varieties for number of branches plant ${ }^{-1}$, number of capsules plant $^{-1}$, capsule length, 1000-seed weight and seed yield. The mustard var. BARI Sarisha-11 produced the highest number of branches plant ${ }^{-1}$, number of capsules plant $^{-1}$, 1000-seed weight resulting the highest seed yield $\left(1.64 \mathrm{t} \mathrm{ha}^{-1}\right)$, followed by BARI Sarisha-15 (1.47 t ha $\left.{ }^{-1}\right)$. The seed yield of BARI Sarisha-11 and BARI Sarisha-15 was not differed significantly, but the growth duration of BARI Sarisha-15 was shorter than the others.
\end{abstract}

\section{Introduction}

Mustard (Brassica sp.) is one of the most important oilseed crops throughout the world after soybean (FAO, 2014). Among the oilseed crops grown in Bangladesh, mustard holds the first position in terms of area and production as of 2,94,737 ha and 1,94,000 tons, respectively (BBS 2013). Mustard seeds contain 40-45\% oil and 20-25\% protein. Mustard is not only a rich source of energy (about $9 \mathrm{kcal} \mathrm{g}^{-1}$ ), but also rich in fat soluble vitamins like A, D, E and $\mathrm{K}$. The oil production is low compared to our demand. For this reason every year a large amount of oil and oil seeds are imported in our country. Increasing production of mustard may be one of the way to minimize demand supply gap of edible oil in the country. Production of mustard can be increased by bringing more lands of haor areas under mustard cultivation. Haor with their unique hydro-ecological characteristics are large bowl shaped floodplain depressions that remains flooded from late May to October. In haor areas of north-eastern districts of our country mostly one crop i.e. boro rice is widely cultivated. Due to flash flood and existence of water for long time it is almost difficult to cultivate more than one crop in that area. After receding of flood water from the comparatively high land of haor areas, there is a greater possibility of growing short duration mustard in this adverse ecosystem and a portion of monocropped land can be brought under double-cropped area. Hence, the experiment was done to find out the suitable mustard variety/varieties for increasing productivity in the haor areas of Sunamganj district. 
Z Ahmed and M A Kashem

\section{Materials and Methods}

The research work was conducted in the haor areas of south Sunamganj upazila of Sunamganj district, during the period of November 2015 to March 2016. The soil of the experimental area was silt-loam in texture. The experimental fields were medium high land with well drained condition. Five mustard varieties viz. BADC 1, SAU Sarisha-3, BARI Sarisha-11, BARI Sarisha-14 and BARI Sarisha-15 were used as test crops. The experiment was laid out in a randomized complete block design with three replications. The unit plot size was $6.5 \mathrm{~m} \mathrm{x} 2.5$ $\mathrm{m}$. Fertilizers were applied at the rate of $115-34-43-27 \mathrm{~kg} \mathrm{ha}^{-1}$ of NPKS in the form of urea, triple super phosphate, muriate of potash and gypsum, respectively. One half of $\mathrm{N}$ and full quantity of other fertilizers were applied as basal during the final land preparation. The remaining $\mathrm{N}$ was top dressed at 30 days after seed sowing (DAS). Seeds of different mustard varieties were sown on 15 November 2015 as broadcast method at the rate of $7 \mathrm{~kg}$ seeds $\mathrm{ha}^{-1}$. Different types of weeds were controlled manually and removed from the field on 7 to 10 December 2015. The crop was irrigated at 35 DAS. Malathion 57 EC @ $2 \mathrm{ml} / \mathrm{L}$ water was sprayed to control aphids at the time of flowering. The crop was harvested plot wise when $90 \%$ capsules were matured. The varieties BADC 1, SAU Sarisha-3, BARI Sarisha-14 and BARI Sarisha-15 were harvested on 24, 14, 5 and 6 February 2016, respectively, while BARI Sarisha-11 was harvested on 9 March 2016.

Data on plant height, branches plant ${ }^{-1}$, capsules plant ${ }^{-1}$, capsule length, seeds capsule ${ }^{-1}$, weight of 1000- seeds, seed yield, stover yield and biological yield were recorded and harvest index was calculated. Data were analyzed by using MSTAT-C computer program and means were compared by Duncan's Multiple Range Test (DMRT) technique (Gomez and Gomez, 1984).

\section{Results and Discussion}

\section{Year round weather pattern of Noagaon village}

At Noagaon of south Sunamganj upazila, August was found as the warmest month of the year. The average temperature in August was $28.2^{0} \mathrm{C}$. The lowest average temperature in the year occured in January when it was around $18.2^{\circ} \mathrm{C}$. The driest month of Noagaon was in December with $6 \mathrm{~mm}$ and $703 \mathrm{~mm}$ of rain in June.

Table 1. Temperature, rainfall and flooding depth pattern around the year at Noagaon

\begin{tabular}{lccccc}
\hline \multicolumn{1}{c}{$\begin{array}{c}\text { Name of the } \\
\text { month }\end{array}$} & \multicolumn{3}{c}{ Temperature ${ }^{0} \mathrm{C}$} & \multirow{2}{*}{ Rainfall (mm) } & $\begin{array}{c}\text { Flooding depth } \\
(\mathrm{m})\end{array}$ \\
\cline { 2 - 4 } & Minimum & Maximum & Average & & 0 \\
January & 11.5 & 25.0 & 18.2 & 13 & 0 \\
February & 13.6 & 27.4 & 20.5 & 23 & 0 \\
March & 17.8 & 31.1 & 24.4 & 93 & 2.5 \\
April & 21.5 & 32.1 & 26.8 & 253 & 4.5 \\
May & 23.0 & 31.3 & 27.1 & 485 & 6.5 \\
June & 24.6 & 30.9 & 27.7 & 703 & 7.0 \\
July & 25.2 & 31.1 & 28.1 & 634 & 6.5 \\
August & 25.2 & 31.3 & 28.2 & 521 & 5.0 \\
September & 25.0 & 31.4 & 28.2 & 394 & 2.0 \\
October & 22.6 & 30.6 & 26.6 & 201 & 0.5 \\
November & 17.8 & 28.6 & 23.2 & 27 & 0 \\
December & 13.2 & 25.9 & 19.5 & 6 & \\
\hline
\end{tabular}


Performance of Mustard Varieties in Haor Area of Bangladesh

The highest $7.0 \mathrm{~m}$ flood water remained in the month of July whereas from November to March no standing water prevailed in the basin like haor areas when different crops can be cultivated.

\section{Effect of variety on yield components of mustard}

All the varieties were significantly differed in respect of plant height and other yield contributing characters except branches plant ${ }^{-1}$. The maximum plant height was observed in BARI Sarisha-11 $(126.33 \mathrm{~cm})$ followed by BADC $1(101.06 \mathrm{~cm})$. But plant height was obtained from BADC 1, SAU Sarisha-3 and BARI Sarisha-15 was statistically identical which was $101.06 \mathrm{~cm}$, $99.65 \mathrm{~cm}$ and $95.23 \mathrm{~cm}$, respectively. The shortest plant $(83.84 \mathrm{~cm})$ was found in BARI Sarisha-14 (Table 2). These results are supported by Islam et. al. (2011). BARI Sarisha-11 produced the maximum number of branches (5.0) plant $^{-1}$ followed by BARI Sarisha-15 (4.93). But all the varieties did not differ significantly in case of number of branches plant ${ }^{-1}$ (Table 2). BARI Sarisha-11 produced significantly the highest number of capsules plant ${ }^{-1}$ (147.53). BADC 1 and BARI Sarisha-15 produced the statistically similar number of capsules plant ${ }^{-1}$ which is 98.96 and 97.96, respectively. The lowest number of capsules (80.16) plant ${ }^{-1}$ was produced by SAU Sarisha-3 which is statistically similar to BARI Sarisha-14 (Table 2). Number of capsules plant ${ }^{-1}$ is a genetically control trait but it can be changed by management manipulation like number of plants per unit area along with fertilizer application rate. BARI Sarisha-11 produced profuse branch which bears more capsules than other varieties. This result is in agreement with the findings of Islam et al. (2013). BARI Sarisha-15 produced the longest capsule $(5.06 \mathrm{~cm})$ followed by BARI Sarisha-14 $(4.96 \mathrm{~cm})$ but both are statistically similar. Capsule length found from SAU Sarisha-3, BARI Sarisha-11 and BADC 1 were statistically identical which were $4.65 \mathrm{~cm}, 4.54 \mathrm{~cm}$ and $4.45 \mathrm{~cm}$, respectively and hence the shortest value for capsule length was from BADC 1 (Table 2). The trial varieties produced significantly different seeds capsule $e^{-1}$ and the maximum number of seeds (22.93) capsule ${ }^{-1}$ was produced by BARI Sarisha-14 which is statistically similar to BARI Sarisha-15 (21.44).

Table 2. Effect of variety on plant height and different yield components of mustard

\begin{tabular}{lcccccc}
\hline Variety & $\begin{array}{c}\text { Plant } \\
\text { height } \\
(\mathrm{cm})\end{array}$ & $\begin{array}{c}\text { Branches } \\
\text { plant }^{-1} \\
\text { (no.) }\end{array}$ & $\begin{array}{c}\text { Capsules } \\
\text { plant }^{-1} \\
(\text { no. })\end{array}$ & $\begin{array}{c}\text { Capsule } \\
\text { Length } \\
(\mathrm{cm})\end{array}$ & $\begin{array}{c}\text { Seeds } \\
\text { Capsule } \\
(\text { no. })\end{array}$ & $\begin{array}{c}1000- \\
\text { seed wt } \\
(\mathrm{g})\end{array}$ \\
\hline BADC 1 & $101.06 \mathrm{~b}$ & $4.73 \mathrm{a}$ & $98.96 \mathrm{~b}$ & $4.45 \mathrm{~b}$ & $9.71 \mathrm{~d}$ & $2.16 \mathrm{~b}$ \\
SAU Sarisha-3 & $95.23 \mathrm{~b}$ & $4.83 \mathrm{a}$ & $80.16 \mathrm{c}$ & $4.65 \mathrm{ab}$ & $17.32 \mathrm{~b}$ & $2.50 \mathrm{ab}$ \\
BARI Sarisha-11 & $126.33 \mathrm{a}$ & $5.00 \mathrm{a}$ & $147.53 \mathrm{a}$ & $4.54 \mathrm{~b}$ & $12.89 \mathrm{c}$ & $3.00 \mathrm{a}$ \\
BARI Sarisha-14 & $83.84 \mathrm{c}$ & $4.76 \mathrm{a}$ & $82.00 \mathrm{c}$ & $4.96 \mathrm{a}$ & $22.93 \mathrm{a}$ & $2.16 \mathrm{~b}$ \\
BARI Sarisha-15 & $99.65 \mathrm{~b}$ & $4.93 \mathrm{a}$ & $97.96 \mathrm{~b}$ & $5.06 \mathrm{a}$ & $21.44 \mathrm{a}$ & $2.50 \mathrm{ab}$ \\
\hline LSD (0.05) & 8.10 & $\mathrm{~ns}$ & 9.51 & 0.40 & 1.86 & 0.69 \\
CV(\%) & 2.92 & 4.86 & 3.43 & 4.52 & 4.04 & 18.69 \\
\hline
\end{tabular}

In a column, figures having common letters (s) do not differ significantly

The number of seeds capsule $e^{-1}$ produced by SAU Sarisha-3, BARI Sarisha-11 and BADC 1 was 17.32, 12.89 and 9.71, respectively are statistically different to the highest value (Table 2). In terms of 1000-seed weight trial varieties showed significant difference and the highest 1000seed weight $(3.0 \mathrm{~g})$ was found in BARI Sarisha-11. 1000-seed weight in case of both SAU 
Z Ahmed and M A Kashem

Sarisha-3 and BARI Sarisha-15 was $2.5 \mathrm{~g}$. The lowest value $(2.16 \mathrm{~g})$ for this parameter was found in BADC 1 and BARI Sarisha-14 varieties (Table 2).

\section{Effect of variety on yield of mustard}

The seeds of the tried varieties were sown at the same date but the plants were harvested in different dates. BARI Sarisha-14 was found to be the shortest in crop duration (82 days) followed by BARI Sarisha-15 (83 days). The duration of SAU Sarisha-3, BADC 1 and BARI Sarisha-11 were 91, 101 and 115 days, respectively (Table 3). The maximum seed yield was found from BARI Sarisha-11 (1.64 t ha-1) followed by BARI Sarisha-15 (1.47 t ha-1) but the difference was statistically insignificant. The seed yield found from SAU Sarisha-3 and BADC 1 was statistically similar which were 1.22 and $1.19 \mathrm{t} \mathrm{ha}^{-1}$, respectively. The lowest seed yield (1.01 t ha ${ }^{-1}$ ) was obtained from the shortest duration variety BARI Sarisha-14 (Table 3). BARI Sarisha-11 produced the highest number of branches plant ${ }^{-1}$, number of capsules plant ${ }^{-1}$, 1000 -seed weight resulted the highest seed yield. This difference in seed yield was probably due to the difference in genetic potential of the varieties, which might have contributed toward the final yield. BARI Sarisha-11 produced the maximum stover weight $\left(3.85 \mathrm{t} \mathrm{ha}^{-1}\right)$ than that of other varieties (Table 3) but all of them did not differ significantly. The maximum biological yield (5.49 $\mathrm{t} \mathrm{ha}^{-1}$ ) was found from BARI Sarisha-11 followed by BARI Sarisha-15 (4.93 t ha $\mathrm{t}^{-1}$ ) but both are statistically similar. Biological yield found from SAU Sarisha-3 and BADC 1 were 4.41 and $4.3 \mathrm{t} \mathrm{ha}^{-1}$, respectively which are statistically identical. The lowest biological yield $(3.41 \mathrm{t}$ $\mathrm{ha}^{-1}$ ) was found from BARI Sarisha-14 followed bt BADC-1 (Table 3). It might be due to higher plant height and long crop duration possessed by BARI Sarisha-11. BARI Sarisha-11 exhibited the highest value (29.96\%) of harvest index followed by BARI Sarisha-15 (29.84\%) and BARISarisha-14 (29.75\%). These results of varietal difference were in agreement with some works of Minir and McNeilly (1986).

Table 3. Crop duration and yield of different mustard varieties

\begin{tabular}{lccccc}
\hline Variety & $\begin{array}{c}\text { Crop } \\
\text { Duration } \\
\text { (days) }\end{array}$ & $\begin{array}{c}\text { Seed Yield } \\
\left(\mathrm{t} \mathrm{ha}^{-1}\right)\end{array}$ & $\begin{array}{c}\text { Stover Yield } \\
\left(\mathrm{t} \mathrm{ha}^{-1}\right)\end{array}$ & $\begin{array}{c}\text { Biological } \\
\text { Yield } \\
\left(\mathrm{t} \mathrm{ha}^{-1}\right)\end{array}$ & $\begin{array}{c}\text { Harvest } \\
\text { Index (\%) }\end{array}$ \\
\hline BADC 1 & 101 & $1.19 \mathrm{~b}$ & $3.11 \mathrm{a}$ & $4.3 \mathrm{~b}$ & $27.76 \mathrm{~b}$ \\
SAU Sarisha-3 & 91 & $1.22 \mathrm{~b}$ & $3.19 \mathrm{a}$ & $4.41 \mathrm{~b}$ & $27.67 \mathrm{~b}$ \\
BARI Sarisha-11 & 115 & $1.64 \mathrm{a}$ & $3.85 \mathrm{a}$ & $5.49 \mathrm{a}$ & $29.96 \mathrm{a}$ \\
BARI Sarisha-14 & 82 & $1.01 \mathrm{c}$ & $2.4 \mathrm{a}$ & $3.41 \mathrm{c}$ & $29.75 \mathrm{a}$ \\
BARI Sarisha-15 & 83 & $1.47 \mathrm{a}$ & $3.46 \mathrm{a}$ & $4.93 \mathrm{ab}$ & $29.84 \mathrm{a}$ \\
\hline LSD (0.05) & - & 0.17 & $\mathrm{~ns}$ & 0.66 & 1.17 \\
CV (\%) & - & 5.05 & 5.73 & 5.38 & 1.48 \\
\hline
\end{tabular}

In a column, figures having common letters (s) do not differ significantly

\section{Conclusion}

The result of this trial revealed that the maximum seed yield $\left(1.64 \mathrm{t} \mathrm{ha}^{-1}\right)$ was produced by the mustard var. BARI Sarisha-11, which was statistically similar to BARI Sarisha-15 (1.47 t ha-1). 
Performance of Mustard Varieties in Haor Area of Bangladesh

BARI Sarisha-15 is also a short duration variety compared to BARI Sarisha- 11 and the short duration is an important factor for selecting variety/varieties for haor areas.

\section{References}

BBS (Bangladesh Bureau of Statistics) 2013. Agriculture Wing, Statistical Pocket Book of Bangladesh, Planning Division, Ministry of Planning, Government of Bangladesh.

FAO (Food and Agriculture Organization of the United Nations) 2014. TerraSTAT database. At:http://www.fao.org/agl//agll/terrastat/.

Gomez, A. A. and A. A. Gomez. 1984. Statistical procedure of Agricultural Research. John Wiley and Sons. New York. pp. 20-215.

Islam, M. N., M. S. Rahman, F. Ahmed, M. S. Alom and M. Akhteruzzaman. 2013. Performance of different HYV mustard varieties with sugarcane (Saccharum officinarum) as intercrop in framers' fields. Bangladesh J. Agril. Res. 38(2): 211-217.

Islam, M. N., F. Ahmed, M. S. A. Khan and W. Sultana. 2011. Varietal trial of HYV mustard at newly developed charland. In charland research 2007-2010, Agronomy Division, Bangladesh Agricultural Research Institute, Joydebpur, Gazipur. pp. 01-04.

Minir, M. and T. McNeilly. 1986. Variation in yield and yield components in six varieties of spring oilseed rape. Pakistan J. Agric. Res. 7: 21-27. 